\title{
Role of Government in Development of Sustainable Ecotourism in Karnataka
}

\author{
Vinayak R Naik* and B C Sanjeevaiah†
}

\section{Abstract}

Ecotourism is a visit to the natural reserved areas like national parks, sanctuaries and biosphere reserves for sightseeing as tourism. The visit of reserved areas by the tourists, the entrepreneurs, the government and the host community, the major agencies or stakeholders in ecotourism, has created numerous effects in the field of ecology, socio-cultural, economic which are indefensible lots of time. Sustainability is also a sober concern. The current article inspects sustainability as an association with all its stakeholders and proposes on preserving equilibrium in the correlation which is necessary to achieve sustainability. The part of rule in attaining sustainability is surveyed and found that it helps in reinstating the essential stability in the association with the stakeholders in ecotourism. Ecotourism in Karnataka is steadily qualified for the consideration of the tourists, the government and the entrepreneurs for clear motive. Karnataka has necessary prospective in ecotourism to cope up with the interests of the tourists, the entrepreneurs and the government but does sustainability study with concern in the schedule of these organizations. An environmental law is one of the most effectual tools for executing sustainability; it needs plenty of provisions to institute synchronization between the stakeholders and hence the goal of sustainability in ecotourism remains unachievable.

\footnotetext{
* Research Scholar, Department of Commerce, Bangalore University, Bangalore, vinayak.aranya@gmail.com

† Professor, Department of Commerce, Bangalore University, Bangalore, dr_bcs@yahoo.com
} 
Keywords: Ecotourism, government, local communities, law, sustainability

\section{Introduction}

The increase in tourism in the twentieth century set the place for the origin of ecotourism mainly because of two motives. Firstly, more tourism has cut down seriously on the natural environment causing extensive defeat to natural resources and secondly, ecotourism or the nature-based tourism is commonly accepted, presenting a clean and more steady, sustainable and commercially viable tourism goods that matched to the comfort of the tourists, entrepreneurs and the governments. The WTO (1998) figures that ecotourism and all nature-related outline of tourism describes roughly $20 \%$ of total international travel (Buckley, Ralf, Pannell, \& John, 1990).

The development of ecotourism has set way to a series of debates on the subject of its capability to transport goods to its stakeholders. The entertaining activities in ecotourism like biking, coach tours, horse safaris, bush walking, hunting, shooting, resort stays, and climbing, downhill skiing etc. gives diverse impacts on the environmental, cultural and natural heritage areas. Likewise, the tourists symbolize the set that is more self-indulgent, pleasureseeking, utilization- alert missing the essential grade of understanding heading the environment and the host community, eventually ensuing into a relationship that directs to a state of difference between the two. The loss of biodiversity and wildlife habitat, the creation of waste and spoiled effluent in areas that have less or no capacity to attract them are the worries in ecotourism. With respect to this concern the United Nations chosen the year 2002 as the International Year of Ecotourism primarily to reconsider the lessons cultured in employing ecotourism, and to spot and endorse forms of ecotourism that leads to the protection of seriously scarce ecosystems, contributing the benefits of the activity with local communities and concerning local cultures (Jena \& Nalin, 2002).

This paper studies the nature of association among the stakeholders who get different quantity of gains and losses 
throughout the course of eco-tourism development and assess the role of law in achieving the sustainability in ecotourism mainly in the perspective of Karnataka.

\section{Need of Study}

This study explored the plans and strategies of government for ecotourism development in Karnataka. Government contribution is required in initial economies where tourism set up and promotion tends to be affected honestly by governments. The ecotourism movement should have a tough focus on knowledge through understanding of local ecosystems and cultural inheritance. Karnataka has devised different plan for prolonged ecotourism development in the state. This plan guarantees preservation of Karnataka's natural and cultural heritage. Ecotourism actions can be enduring essential means for economic development in the Karnataka. The objective of this study is to look at the various plans of Karnataka describing to ecotourism development. The study also analyzes the challenges and projection of ecotourism development in Karnataka (Kothari et al, 1999).

\section{Literature Review}

Karnataka has extensive record of proficient management of Forestry and Wildlife. The total geographical area in the State is 1, 91,791 sq. kms out of which the forest area is about 43,356.95 sq. kms which comprise about 22.6\%. The Karnataka Forest Act, 1963 and Rules 1969 legalize functioning in the forest areas. The State has 5 National Parks and 22 Wildlife Sanctuaries covering an area of 6576.76 sq. $\mathrm{kms}$ which forms nearly $15.17 \%$ of the total forest area as protected area. Wildlife (Protection) Act was passed during 1972 by Government of India to grant protection of wild animals, birds and plants and with a vision to endorse the ecological and environmental security of the country. The elephant population in India is around 25,000 of which the estimated population in Karnataka is around 5590 (Census 2010), which constitutes about $22 \%$ of the total population (http://karnatakaforest.gov.in, 2004). 
Table 1. National Park of Karnataka

\begin{tabular}{||c||c||r||c||}
\hline $\begin{array}{c}\text { Name of the National } \\
\text { Parks }\end{array}$ & $\begin{array}{c}\text { Area } \\
\text { (sq.km) }\end{array}$ & Nearest Dist. HQ & $\begin{array}{c}\text { Season to } \\
\text { Visit }\end{array}$ \\
\hline \hline Anshi National Park & 417.34 & Karwar 60 & Nov-Jun \\
Bangalore 580 & Bamarajnagar 52 & Jun-Oct \\
\hline \hline Bandipur National Park & 872.24 & Bangalore 218 & \\
\hline \hline Bannerghatta National Park & 260.51 & Udupi 90 & All Seasons \\
\hline \hline Kudremukha National Park & 600.57 & Bangalore 263 & Dec-May \\
\hline \hline Nagarahole National Park & 643.39 & Mysore 120 & Sept.-Mar \\
\hline \hline
\end{tabular}

Source: (http:/ / karnatakaforest.gov.in, 2004)

\section{Bird Sanctuaries in Karnataka}

Adichunchanagiri Peacock Sanctuary, Arabithittu Wildlife Sanctuary, Attiveri Bird Sanctuary, BRT Wildlife Sanctuary, Bhadra Wildlife Sanctuary, Brahmagiri Wildlife Sanctuary, Cauvery Wildlife Sanctuary, Dandeli Wildlife Sanctuary, Doraji Bear Sanctuary, Ghataprabha Wildlife Sanctuary, Gudavi Bird Sanctuary, Melukote Wildlife Sanctuary, Mookambika Wildlife Sanctuary, Nugu Wildlife Sanctuary, Pushpagiri Wildlife Sanctuary, Ranganathittu Bird Sanctuary, Ranibennur Blackbuck Sanctuary, Sharavathi Wildlife Sanctuary, Shettihalli Wildlife Sanctuary, Someshwara Wildlife Sanctuary, Thalakaveri Wildlife Sanctuary, Bhimgad Wildlife Sanctuary, Rangayyanadurga Fourhorned antelope Sanctuary, Chincholi Wildlife Sanctuary, Ramadevarabetta Vulture Sanctuary (http://karnatakaforest. gov.in, 2004) (Kothari et.al, 1999). 


\section{Table 2. Tiger Reserve of Karnataka}

\begin{tabular}{||l||c||c||}
\hline $\begin{array}{c}\text { Name of the Tiger } \\
\text { Reserve }\end{array}$ & $\begin{array}{c}\text { Area (sq. } \\
\text { kms) }\end{array}$ & $\begin{array}{c}\text { Year of } \\
\text { Establishment }\end{array}$ \\
\hline \hline Bandipur & 870 & 1973 \\
\hline \hline Bhadra & 492 & 1998 \\
\hline \hline Nagarahole & 643 & 2000 \\
\hline \hline Dandeli-Anshi & 475 & 2006 \\
\hline \hline BRT & 539.52 & 2011 \\
\hline
\end{tabular}

Source: (http:/ / karnatakaforest.gov.in, 2004)

\section{Table 3. Reserve of Karnataka}

\begin{tabular}{|c|c|c|}
\hline Name of the Reserve & $\begin{array}{c}\text { Area } \\
\text { (sq. } \\
\text { kms) }\end{array}$ & $\begin{array}{c}\text { Year of } \\
\text { Establishment }\end{array}$ \\
\hline $\begin{array}{l}\text { Bankapura Peacock Conservation } \\
\text { Reserve }\end{array}$ & 0.56 & 2006 \\
\hline $\begin{array}{l}\text { Mydhanahalli(Jayamangali) Black } \\
\text { Buck Conservation Reserve }\end{array}$ & 3.23 & 2007 \\
\hline \begin{tabular}{|l} 
Basur Amruth Mahal Kaval \\
Conservation Reserve
\end{tabular} & 7.36 & 2011 \\
\hline Hornbill Conservation Reserve & 52.5 & 2011 \\
\hline Aghanashini Conservation Reserve & 299.52 & 2011 \\
\hline Bedthi Conservation Reserve & 57.3 & 2011 \\
\hline $\begin{array}{l}\text { Shalmale Riparian Bio-system } \\
\text { Conservation Reserve }\end{array}$ & 4.89 & 2012 \\
\hline Kokkare Bellur Community Reserve & 3.12 & 2007 \\
\hline
\end{tabular}

Source: (http://karnatakaforest.gov.in, 2004) 


\section{Legal Aspects of Ecotourism}

In India, there is bounty of rules created with the matter of environment protection. The Articles 48-A, 51-A (g) and 51-A (j) of the Indian Constitution says that it is the primary duty of all its citizen of the country to add in the protection of environment. The Forest Act 1927, The Wildlife (Protection) Act 1972, The Water (Prevention \& Control of Pollution) Act 1974, The Forest (Conservation) Act \& Rules 1980 1981, The Air (Prevention \& Control of Pollution) Act 1981, The Environment (Protection) Act and Rules 1986; The Water (Prevention and Control of Pollution) Cess (Amendment) Act 2003, in addition with various policy documents like National Tourism Policy 2002, Policy and Guidelines on Ecotourism in India 1998, provide various official measures for environment protection. The main question that arises here is "Does law creates synchronization among the stakeholders in ecotourism so as to achieve the goal of sustainability? All the legal measures passed above have two main features - first, the procedures are mainly of defensive nature fairly than conservationist. Second, the measures are trading with the natural environment and not with the sustainability- a concept that preserve a positive relationship among all the stakeholders associated with the environment (W. and Kulkarni, Sharad, 1983).

The environment associated laws in the post-independence period endorsed the government to implement a total run over the forests and forest resources preserving the customary rights of people living in the forests (Kulkarni \& Sharad, 1983). The National Forest Policy in 1952 started the core of the Forest policy to fulfil the 'national needs' which were recognized in terms of industrial and commercial development crucial for the national economy instead of keeping the rights of the local people and communities (CSE 1985). Likewise, the Wildlife (Protection) Act 1972 (WPA) is identified as basically an excessive and rigid kit rather than a positive agent of change. This Act reject people from the route of formation of safe place and national park and their management break the symbiotic relationship between the forest residence society and the forests and abrogates their traditional rights. The social, cultural, political, spiritual and above all sustenance values of forests and forest produce, without figuring main concern on 
the outline of the 'state-sponsored conservation' (Jena, Nalin, 2002). One can see a conflict or divergence between the welfare of the local people and the preservationists, which acquires the violent expressions sometimes (Kothari, A et.al, 1999). Such shift has made the laws tactless to the symbiotic relationship between the tribal's and the forest and thus untenable in character (Buckley, Ralf, Pannell, \& John, 1990).

Ecotourism, too, is causative in the development of variance between the community and the authorities. In addition, the environmental deprivation at the hands of ecotourism, as conferred above, leaves some troubling impressions. The main source of clash in ecotourism is based on the use of traditional habitats (belonging to the local people) by the outsiders (tourists) that make a exhibit of an unconcerned attitude of the authorities towards the forest communities (Chaudhary, \& Ashok, 1996). Furthermore, the level of damage to the forest environment may be more because of the indefensible tourism development than the local people who are deprived of entrance into the forest area on the pretext of causing damage to the forest environment. In the existing scheme of stuff, it is the tourists, the government and the entrepreneurs who have been benefited.

The government guidelines of 1998 on ecotourism development recommend a careful move toward, scientific planning, useful control and nonstop monitoring of the development process in perspective of ecotourism. The National Tourism Policy-2002 identifies sustainability as one of its principles. It states (Jena \& Nalin, 2002).

Sustainability should serve as a guide star for the new policy. The development and management policy should be so vocational as to ensure that tourism mostly acts as a fireless industry and its ecological footprints wait as soft as possible. No one occupied, directly or indirectly, the tourism industry should be permitted to safe short-term growth by routing to the shady side of tourism (Chaudhary \& Ashok, 1996).

Neither over-utilization of natural resources should be allowed nor the moving ability of the tourist-sites unnoticed" (Jena \& Nalin, 2002). 


\section{Acts, Rules, Manuals of Karnataka Forest Department}

Karnataka Forest Manual, 1976, Karnataka Forest Act, 1963, Karnataka Forest Rules, 1969, Karnataka Tree Preservation Act, 1976, Karnataka Tree Preservation Rules, 1977, Wildlife Protection Act, 1972, Wildlife Protection (Karnataka) Rules, 1973, BioDiversity Act, 2002, Bio-Diversity Rules, 2004, Environment (Protection) Act, 1986, Environment (Protection) Rules, 1986, Forest Conservation Act, 1980, Forest Conservation Rules, 1981, Forest Conservation Rules, 2003.

The winning course of actions, effect in India rely ahead on numeral factors which necessitate a right management involving different ministries and departments at the Central and State levels, the function of the tourism developers and law-enforcing agencies, and a proper evaluation and adjustment of local/public interests. Likewise, the principles submitted in the policy are added 'note of caution' instead of forming the bit of key goals that talks more recognition of diverse tourism resources and products and their use for tourism.

\section{Karnataka Government to Set up Eco-tourism Board}

Eco-tourism in the state is predicted to get a big enhancement with the state cabinet for agreeing the scheme to set up Eco-Tourism Development Board. The forest minister will be the board's chairman. Broadcasting the decision, higher education minister said the initiative would help the government greatly in protecting the wildlife, generating awareness about it, encouraging ecotourism, forest safaris and also avoid scratch to eco-system in the name of tourism. Madhya Pradesh and Himachal Pradesh have previously set up such boards to enhance eco-tourism. Higher education minister said the board would get private investments to the state and gain consultancy (The Hindu, 2011).

Tourist spots like Bandipur National Park would witness enormous progress in tapping the tourism prospective; he added (http:/ / karnatakaforest.gov.in, 2004). 


\section{Ecotourism guidelines}

It is significant to engage all stakeholders in executing ecotourism guidelines. Synergy and collaboration amongst the Central Government, State Governments, hospitality sector, State Forest Departments, Protected Area managements, and local communities and civil society foundation is vital for guaranteeing successful carrying out of the guidelines (Iyer, 1996).

\section{State Governments}

\subsubsection{The State Government must develop a State-level} Ecotourism Strategy-A comprehensive plan to ensure (Kulkarni, \& Sharad, 1983):

Wasteland conservation in ecologically sensitive landscapes.

Local area participation and benefit-sharing.

Best environmental design and use of locally produced and sustainable materials

Protection, Education and training.

Evaluation and sufficient supervision of the impact of ecotourism activities.

Power building of local communities in planning, managing ecotourism facilities.

The State-level Ecotourism Strategy must be in tune with the outline of guidelines provided here. Ecologically perceptive land use strategy that should be approved for the landscape adjoining protected areas. Enough provisions must be made to guarantee that ecotourism does not get consign to purely high-end, special tourism, leaving out local communities. Appropriate changes in State rules and regulations must be accepted in order to guarantee adherence to these standards by tourist developers and operators. All States should report the State level Ecotourism Strategy by December 31, 2011, and set the same in the public domain, in the local language also (Chaudhary \& Ashok, 1996). 
No new tourist amenities are to be put up on forest lands. This is in fulfillment with the Wildlife (Protection) Act, 1972, and the directions of the Honorable Supreme Court (Kothari, et.al, 1999).

The State Government must extend the system by which gate receipts from Protected Areas should be collected by the Protected Area management, and not leave as returns to the State Exchequer. This will guarantee that resources produced from tourism can be allotted for protection, conservation and local livelihood development.

The State Forest Department should be the authority in case of any clash regarding the ecological appeal of any tourism plans, whether Protected Area Management, private entity, temple board or community, as the welfare of wildlife and Protected Areas/ biodiversity takes precedence over tourism.

The Chief Wildlife Warden of the State must make sure that each Protected Area will set up an ecotourism plan, as part of the Management Plan/Annual Plan of Operation/ Tiger Conservation Plan. A site-specific Ecotourism map for each Protected Area must be ready and approved by the State government by December 31, 2011, and place in the public domain; in the local language also.

The Chief Wildlife Warden (CWLW) of the State shall increase a monitoring mechanism, approximate carrying capacity (model mechanism to calculate carrying capacity, provided in Annexure II), outline tourism zones, and choose the area free to tourism on the basis of objective, scientific criteria.

A State Level Steering Committee to be comprised under the chairmanship of the Chief Minister for quarterly review vis-à-vis the recommendations contained in the State-level Ecotourism Strategy. The Chief Wildlife Warden of the State shall be the Member Convener committee. The State Government will fix its composition and rules of practice. Each State should comprise State Level Steering Committees by December 31, 2011, and the names of its members should be put in the public domain. The Committee should have demonstration from local communities that live in and around Protected Areas, tribal welfare department, Panchayat Raj Institution and Civil Society Institutions. 
As part of the State-level Ecotourism Strategy, the State government should charge a "local conservation cess" as a gain of turn-over, on all privately run tourist services within $5 \mathrm{~km}$ of the boundary of a Protected Area. The rate of cess should be determined by the State Government, and the monies thus collected should be earmarked to fund Protected Area management, conservation and local livelihood development, and not go to the State Exchequer as discussed in 2.1.4 above. Each State Government should notify the local conservation cess by December 31, 2011. The basis for a local conservation cess should be plainly describe to the public at large, including throughout clear signage at local tourist facilities.

Financial assistance/ incentives must be offered for communities/individuals who hold returns lands exterior to protected areas, to switch these lands to forest status. The value of these lands for wildlife will be improved, even as it improves the income of the landowner from ecotourism.

A Local Advisory Committee (hereinafter referred to as LAC) must be represented for each restricted Area by the State government. The LAC will have the following mandate:

To reconsider the State Ecotourism Strategy with respect to the Protected Area and make proposal to the State government.

To assurance site restrictions on buildings and infrastructures in private areas within core/critical tiger habitat/National Park/Sanctuary or buffer zone with strip value.

To direct local and state government on concern specific to development of ecological-tourism in non-forest areas of ecological tourism zones etc.

Frequently examine all tourist services falling within $5 \mathrm{~km}$ of a Protected Area environmental authorization, coverage area, ownership, type of construction, number of employees etc, for mitigation process.

Regularly supervise activities of tour operators to make sure that they do not cause trouble to animals while taking visitors into the Protected Area. 


\section{Research Methodology}

The study is descriptive in nature and has the 'fact-finding' survey method. Primary data has been collected by administering interview schedules to the respondents and researcher has made field visits to five national parks and interacted with local communities and authorities using a completed questionnaire technique. Data required for the research has been collected from both primary and secondary sources. Primary data has been collected from the respondents, namely, local people and forest officials.

Secondary data has been collected from reputed journals, magazines, articles, conference proceedings, news papers, televisions, books, e-books, dedicated to the tourism industry and house journals of industry bodies such as FICCI and CII.

\section{Selection of Sample Units}

Before go aboard survey, working plan of various national park divisions were evaluated to obtain overall information about the role of sustainability of ecotourism and welfare of local communities. After consultation and discussion with forest officials, field trips were carried out. Main districts that were focused for the study were Bangalore, Uttara-Kannada, Chikkamagaluru, Chamarajanagar, Mysore and Kodagu

Following national parks were finally chosen for the current study

- Bannaerghatta National Park, located in Bangalore District, Karnataka, India.

- Anshi National Park, located in Uttara Kannada District, Karnataka, India.

- Kudremukh National Park, located in Chikkamagaluru District, Karnataka, India.

- Bandipur National Park, located in Chamarajanagar District, Karnataka, India.

- Nagarahole National Park also known as "Rajiv Gandhi National Park" located in Kodagu district and Mysore district, Karnataka, India. 


\section{Results and Recommendations}

The study discloses that some activities may be taken for the ecotourism development in Karnataka by government. Subsequent are the outcome researcher gained from sample population such as local communities and forest officials during the study.

As said by Forest officials the World Tourism Report defines sustainable tourism "as a replica of economic development that exemplifies stewardship of environment and sensitivity to community and cultural aspirations." A new element has been added by sustainable tourism. It takes into report both the conservation and preservation of the physical and cultural environment of a particular region. So, under sustainable tourism, natural resources of the locality are to be placed within the parameters which won't humiliate the natural assets and the traditional livelihood of the community

According to national forest officials under the support of this novel approach, efforts are on to give confidence to the community members to set the speed and direction of tourism development in a way consistent with their lifestyle and tradition in order to value the cultural heritage of every region. Integrated community participation between the local people, the local government and national level plan makers has to be accepted.

Ecology and economy are becoming more interlinked. Protection of the environment land, development of tourism should not be seen as separate challenges. In order to be efficiently sustainable, tourism must be environmentally sustainable to both the natural and the human environments. The government must be certain that the local people also need to contribute in ecotourism development for their social, ecological, economic and cultural benefits.

It is the responsibility of the local community to sensibly handle their local assets for their own improvement and for a better quality of life. Hygienic physical atmosphere and protected environment would provide improved quality of life to the local community and the tourist alike.

As of national park authorities and government officials, the onslaught of colonialism and the mounting force of commercial 
and consumer demand which wrecked havoc upon the native community are affecting reminders for more careful utilization of the regional assets. It is of salience that World Tourism Report senses the isolation of local inhabitants and considers various sensitive issues while surfacing the strategies of sustainable tourism. It understands the sense of denial and marginalization of the local inhabitants. In its principles for sustainable tourism the Report focuses upon the broader vision which includes following guidelines:

Tourism planning, development and operations should be in the will of sustainable development in being cross-sectoral and included, concerning different government agencies, private corporations, citizens groups and individuals so as to provide for the extensive benefits.

Agencies, corporations, groups and individuals should track ethical principle which follows the culture and environment of the host area, the economy and traditional way of life, the community and traditional behaviour, leadership and political patterns.

Due regard to be set to the protection and suitable economic use of the natural and human environment in the host areas to be framed.

Tourism should be taking on with justice in mind, with the thought of access to a fair distribution of benefits and costs among tourism promoters and host peoples and their areas.

Good information, study and communication on the nature of tourism and its possessions on the human and cultural environment should be available earlier to and during development. This information must be known to all parties, plus the local people, so that they are in a situation to participate in and control the direction of, development in their area. This would emphasize the community spirit and reverse the sense of hostility.

Local people must be encouraged to carry out leadership roles in the planning and development of their local assets with the aid of government, financial, business and other interests.

There should be collective environmental, social and economic planning to tie with existing uses, ways of life and environmental considerations. 
Careful supervising should be done to permit local population to take benefit of chance offered by new change.

Researchers visited Kenya for departmental excursion and found lots of surprising particulars about it. Kenya has rich cultural heritages where in some areas for many centuries used to protect the flora and fauna. There blessed trees and forest in Kenya were under the supervision of the local communities through their local traditions and taboos. Some trees like 'mugumo tree' are a sacred tree which is highly protected. Kenya has 'Kaya forests' along the Coastal region which are sheltered by the local people through customs and beliefs. The Kenya government has recognized the conservation of indigenous forests by the local people and has allowed them to control and protect some of these forests. The Kenyan government has created an enabling environment for ecotourism to thrive. It works closer with NGOs, International organization like UNEP which has its Head Quarters in Nairobi Kenya. The government formed organizations like NEMA to conduct environmental brunt assessment, environmental audit to the existing properties.

Statistics from studies of ecotourism says that, in Kenya for instance, a healthy lion can make thousands of dollars in tourism revenue every year, and an elephant herd can report hundreds of thousands tourism dollars. But, as ecotourism promotes emphasize on these natural resources that it must be preserved so that the economic benefit can be realized over the course of years. Actually, wildlife and biodiversity-focused tourism ranks world's top employers. In economic point of view Kenya's twenty percentage of GDP is generated from ecotourism. It shows that their main revenue is from Ecotourism and they are largely depending on this source of economy. Karnataka is also rich in its biodiversity. So government agencies and local communities should come further to make it more preservative and successful through effective laws, policies, and acts.

\section{Conclusion}

The current drift in ecotourism in Karnataka seems to be divided into two major considerations - environment conservation and 
tourism promotion. The conservation task emphasizes the need for protection of environment by controlling the human activity in the reserved areas. Even the traditional communities living in the reserved areas were thrown out. The government reserved its right to take out revenues from the forests and forest produce and promoted ecotourism to increase its revenues. These practices benefited the government by getting more revenues from the reserved areas, and the entrepreneurs who got business through structured and packaged tours to the natural areas. The host community found aggressive to cop up with the pressures of tourism development. Sustainability cannot be maintained as achieved if it marginalizes the local community even though the tourists, the government and the entrepreneurs are benefited. So, the ecotourism in Karnataka need to be developed by revising the laws for reaching the objectives of sustainability.

\section{References}

Ralf, B., \& John, P. (1990). Environmental impacts of tourism and recreation in national parks and conservation reserves. The Journal Tourism Studies, 293-319.

Chaudhary, A. (1996). Conservation, conflict and struggle: Rajaji national park. New Delhi: Vikas Publishing House.

Gopal Iyer, K. (1996). Sustainable Development: Ecological and Sociocultural Dimensions. New Delhi: Vikas Publishing House.

Karnataka Forest Department, (2004). About us. Retrieved from website: http://karnatakaforest.gov.in

Jena, N.(2002). National Parks and Sanctuaries vs People's Rights: Some Issues of Concern. New Delhi: Vikas Publishing House.

Kothari, A et. al. (1999). Management of National Parks and Sanctuaries in India. New Delhi: Indian Institute of Public Administration.

W, \& Kulkarni, Sharad. (1983). Towards a New Forest Policy: People's Rights and Environmental Needs. New Delhi: Indian Social Institute. 